\title{
PERAN KEPALA SEKOLAH SEBAGAI SUPERVISOR DALAM MENGEFEKTIFKAN PROSES PEMBELAJARAN PPKn DI SMP NEGERI 10 MATARAM
}

\author{
Maria Stevania Nelviana Pitang' ${ }^{1}$ Kamaluddin²
}

${ }^{1}$ Pendidikan Pancasila dan Kewarganegaraan, Universitas Muhammadiyah Mataram, mariastevania.pitang10@gmail.com ${ }^{2}$ Pendidikan Pancasila dan Kewarganegaraan, Universitas Muhammadiyah Mataram, kamaluddin@gmail.com

\begin{tabular}{l} 
INFO ARTIKEL \\
\hline Riwayat Artikel: \\
Diterima: $\quad$ 15-Februari- \\
2018 \\
Disetujui: 20-Maret-2018
\end{tabular}

Kata Kunci:

Peran

Kepala sekolah

Supervisor

Pembelajaran

\section{A. LATAR BELAKANG}

Mutu pendidikan mengacu pada masukan, luaran, dan dampaknya. Mutu masukan dapat dilihat dari beberapa sisi. Pertama, kondisi baik atau tidaknya masukan sumber daya manusia seperti kepala sekolah, guru, laboran, staf tata usaha dan siswa. Kedua, memenuhi atau tidaknya kriteria masukan material berupa alat peraga, buku-buku, kurikulum, prasarana dan sarana sekolah. Ketiga, memenuhi atau tidaknya kriteria masukan yang perangkat lunak, seperti

\begin{abstract}
Abstrak: Kepala sekolah sebagai pemimpin lembaga pendidikan sekolah mempunyai peran penting sebagai supervisor. Tujuan penelitian ini untuk mengetahui peran kepala sekolah sebagai supervisor dalam mengefektifkan proses pembelajaran PPKn dan apa saja faktor pendukung dan penghambat supervisor dalam mengefektifkan proses pembelajaran PPKn di SMP Negeri 10 Mataram. Metode yang digunakan dalam penelitian ini yaitu metode kualitatif dengan pendekatan deskriptif. Tehnik pengumpulan data yang digunakan adalah observasi, wawancara dan dokumentasi. Subyek peneliti adalah kepala sekolah dan guru PPKn. Tehnik analisis data digunakan adalah data reduction, data display dan conclusion drawing/verification. Hasil penelitian menunjukkan bahwa fungsi kepala sekolah adalah sebagai supervisi kepada guru yaitu memberikan bimbingan, arahan agar guru bisa melaksanakan tugasnya dengan professional dan bisa mengusai kompetensi berupa kompetensi sosial, pedagogik, professional dan kepribadian sedangkan faktor pendukung dan faktor penghambat supervisor akademik, faktor pendukung supervisor akademik adalah para guru selalu siap untuk disupervisor oleh kepala sekolah. Faktor penghambat supervisor akademik ini adalah adanya beberapa kesulitan yang dialami oleh kepala sekolah yang berupa jika kepala sekolah mensupervisor guru yang bukan bidang studi yang menjadi background pendidikan kepala sekolah.
\end{abstract}

\begin{abstract}
Principals as leaders of school education institutions have an important role as supervisors. The purpose of this study was to determine the role of the principal as a supervisor in streamlining the PPKn learning process and what are the supporting factors and inhibitors of supervisors in making the PPKn learning process effective at Mataram State Middle School 10. The method used in this study is a qualitative method with a descriptive approach. Data collection techniques used are observation, interviews and documentation. The research subjects were the school principal and the PPKn teacher. Data analysis techniques used are data reduction, data display and conclusion drawing / verification. The results showed that the principal's function was as supervision of the teacher, namely providing guidance, direction so that the teacher could carry out his duties professionally and could control competencies in the form of social, pedagogical, professional and personality competencies while supporting factors and inhibiting factors of academic supervisors, supporting factors of academic supervisors the teachers are always ready to be supervised by the principal. The inhibiting factor of this academic supervisor is that there are some difficulties experienced by the principal in the form of if the principal supports supervisors who are not in the field of study who are the educational background of the principal
\end{abstract}

peraturan dan struktur organisasi. Keempat, mutu masukan yang bersifat harapan dan kebutuhan, seperti visi, motivasi, ketekunan dan cita-cita. Sudarwan Danim (2012:53) mengatakan

Mutu pendidikan akan tercipta apabila penyelenggaraan pendidikan dapat dilaksanakan secara efektif dalam kerangka kerja yang konseptual. Efektivitas penyelenggaraan pendidikan akan menghasilkan mutu pendidikan yang diharapkan sesuai dengan visi, misi, dan tujuan dari sistem pembelajaran yang dilaksanakan di lingkungan sekolah. Peningkatan 
mutu sekolah secara umum dapat diambil bersamaan dengan strategi membangun akuntabilitas pendidikan berdasarkan pola kepemimpinan, untuk itu keberhasilan suatu lembaga pendidikan memerlukan seseorang yang mampu dalam memimpin sebuah lembaga pendidikan yang disebut sebagai kepala sekolah.

Kepala sekolah adalah seorang tenaga fungsional guru yang diberi tugas untuk memimpin suatu sekolah, tempat diselenggarakan proses belajar mengajar atau terjadinya interaksi antara guru yang memberi pelajaran dan siswa yang menerima pelajaran[1]. Kepala sekolah sebagai pemimpin lembaga pendidikan sekolah mempunyai peran penting sebagai supervisor. Tugas utama kepala sekolah ialah membina dan mengembangkan sekolahnya agar pendidikan dan pengajaran makin efektif dan efisien. Hal ini hanya dapat dilaksanakan dengan baik dan lancar apabila ada kerja sama yang harmonis dengan seluruh guru sekolah. Oleh karena itu yang harus dilakukan ialah membina kerjasama antara kepala sekolah dengan para guru sehingga terjadi hubungan yang baik.

Hasil observasi menunjukkab bahwa masih banyak permasalahan yang dilakukan oleh guru. Permasalahan yang dijumpai adalah disiplin guru, terutama disiplin guru dalam memasuki kelas pada saat kegiatan pembelajaran di kelas. Kemudian masih ada guru yang tidak menggunakan metode yang bervariasi bahkan kurang menggunakan alat peraga pada saat KBM serta tidak memanfatakan teknologi sebagai sarana belajar khususnya pada mata pelajaran Pendidikan Pancasila dan Kewarganegaraan. Hal ini dapat mengakibatkan siswa tidak menerima pelajaran secara utuh dan tidak efektif.

Dalam rangka melakukan peran dan fungsinya, kepala sekolah harus memiliki strategi yang tepat untuk memberikan dorongan dan motivasi kepada tenaga kependidikan (guru) untuk meningkatakan profesinya. Dalam pelaksanaanya pengelolaan setiap komponen sitem pendidikan tidak terlepas dari fungsi-fungsi kepala sekolah yaitu[2]:

1) perencanaan (planing), perencanaan pada dasarnya menjawab pertanyaan tentang apa yang harus dilakukan, oleh siapa dan kapan dilakukan. Kepala sekolah harus menyiapkan rencana tahunan yang dipersiapakan untuk tahun ajaran berikutnya.

2) perorganisasian (organizing), Kepala Sekolah perlu mengadakan pembagian kerja yang jelas bagi guru-guru yang menjadi anak buahnya. Dengan pembagian kerja yang baik, pelimpahan wewenang dan tanggung jawab yang tepat serta mengingat prinsip-prinsip pengorganisasian kiranya kegiatan sekolah akan berjalan lancar dan tujuan dapat tercapai.

3) pengarahan (directing) adalah kegiatan membimbing anak buah dengan jalan memberi perintah (komando), memberi petunjuk, mendukung semangat kerja, menegakkan disiplin, memberi usaha lainnya agar mereka dalam melakukan pekerjaan mengikuti arahyang ditetapkan dalam petunjuk, peraturan atau pedoman yang telah ditetapkan.

4) pengkoordinasian (coordinating) adalah kegiatan menghubugkan orang-orang dan tugastugas sehingga terjalin keserasian dan keselarasan, keputusan, kebijaksanaan, tindakan, langkah sikap serta tercegah dari timbulnya pertentamgan, kekacauan, duplikasi dan kekosongan tindakan.

5) pengawasan (controlling) adalah kegiatan usaha agar pelaksanaan pekerjaan serta hasil kerja sesuai dengan rencana, perintah, petunjuk, atau ketentuan-ketentuan lain yang telah diterapkan.

Fungsi-fungsi tersebut bertujuan untuk mengatur proses kegiatan pendidikan, termasuk di lembaga sekolah sebagai wahana pendidikan, agar dapat berjalan dengan baik sehingga pada gilirannya tercapai efektifitas dan efisiensi. Selain itu kepala sekolah juga harus melakukan kunjungan kelas atau observasi kelas pada saat guru sedang mengajar dengan tujuan melihat kondisi dan situasi serta membantu guru yang bersangkutan menghadapi masalah atau kesulitan selama mengadakan kegiatan pembelajaran. Kunjungan kelas dilakukan dalam upaya kepala sekolah memperoleh data tentang keadaan sebenarnya mengenai kemampuan dan keterampilan guru dalam mengajar.

Tujuan penelitian ini untuk mengetahui peran kepala sekolah sebagai supervisor dalam mengefektifkan proses pembelajaran PPKn dan apa saja faktor pendukung dan penghambat supervisor dalam mengefektifkan proses pembelajaran PPKn di SMP Negeri 10 Mataram.

\section{B. METODE PENELITIAN}

1. Metode Penelitian yang Digunakan

Metode yang digunakan dalam penelitian ini yaitu metode kualitatif dengan pendekatan deskriptif. Bogdan dan Taylor dalam Moleong mendefenisikan metode kualitatif sebagai prosedur penelitian yang menggunakan data deskriptif berupa kata-kata tertulis atau lisan dari orang-orang dan perilaku yang diamati[3] Metode penelitian kualitatif adalah metode penelitian yang berlandaskan pada filsafat postpositivisme, digunakan untuk meneliti pada kondisi objek yang alamiah (sebagai lawannya adalah eksperimen) dimana peneliti adalah sebagai instrumen kunci, teknik pengumpulan data dilakukan secara triangulasi (gabungan), analisis data bersifat induktif/kualitatif, dan hasil penelitian kualitatif lebih menekankan makna dari pada generalisasi"[4].

Selanjutnya penelitian deskriptif digunakan untuk memecahkan atau menjawab permasalahan yang sedang dihadapi pada situasi sekarang. Dilakukan dengan menempuh langkah-langkah pengumpulan, klasifikasi, dan analisis data, membuat kesimpulan dan laporan 
dengan tujuan utama membuat gambaran tentang sesuatu keadaan secara obyektif dalam suatu deskripsi situasi.

Berdasarkan hal tersebut maka dalam penelitian ini, berusaha untuk menuturkan pemecahan masalah yang ada saat ini berdasarkan data-data. Di samping itu juga menyajikan data,menganalisis dan menginterprestasi, serta bersifat komperatif dan korelatif. Maka peneliti akan memaparkan dan menggambarkan data-data yang telah diperoleh yang berkaitan dengan"Peran Kepala Sekolah Sebagai Supervisor Dalam Mengefektifkan Proses Pembelajaran PPKn di SMP Negeri 10 Mataram Tahun pelajaran 2017/2018 “.

2. Lokasi Penelitian

Penelitian ini dilaksanakan di SMP Negeri 10 Mataram yang terletak di jalan Adi Sucipto No.07, Kecamatan Ampenan, kelurahan Ampenan Utara Kota Mataram tahun pelajaran 2017/2018.

\section{Penentuan Subyek Penelitian}

Subyek adalah sumber yang dapat memberikan informasi atas permasalahan yang diteliti oleh penulis. Subyek penelitian adalah subyek yang dituju untuk diteliti oleh peneliti. Jadi, subyek penelitian itu merupakan sumber informasi yang menggali untuk mengungkap fakta-fakta di lapangan[5]. Penentuan subyek penelitian atau sampel dalam penelitian kualitatif berbeda dengan penelitian kuantitatif.

Penentuan sampel dalam penelitian kualitatif (naturalistik) sangat berbeda dengan penentuan sampel kuantitatif (konvensional)[6]. Penentuan sampel tidak didasarkan pada perhitungan statistik. Sampel yang dipilih berfungsi untuk mendapatkan informasi yang maksimum, bukan untuk digeneralisasaikan.

Dalam penelitian kualitatif, penentuan subyek harus memiliki kualifikasi yakni harus mengetahui,memahami dan mengalami sehingga data yang diperoleh akan lebih valid. Peneliti ini akan menggunakan teknik purposive sampling. Purposive sampling merupakan teknik pengambilan sampel yang ditentukan dengan menyesuaikan pada tujuan penelitian atau pertimbangan tertentu[7]. Sebagaimana yang diketahui dalam penelitian kualitatif, peneliti akan memasuki situasi sosial tertentu, melakukan pengamatan dan wawancara kepada orang-orang yang dipandang tahu tentang situasi sosial.

Dalam penelitian ini yang menjadi subyek penelitian adalah kepala sekolah dan guru-guru di SMPN 10 Mataram.

\section{Jenis dan Sumber Data}

Dalam pelaksanaan penelitian, peneliti memerlukan data yang akurat agar hasil kajian dapat dipertanggungjawabkan kebenarannya. Dalam melaksanakan penelitian, ada dua jenis data yaitu data kualitatif[5]. Jenis data dalam penelitian ini adalah data kualitatif yaitu dengan cara menjelaskan secara sistematis, analisis dan logis dari permasalahan.
Sumber data dalam penelitian ini adalah informasi atau subyek dan benda serta situasi lingkungan secara keseluruhan dari mana data-data yang relevan untuk terjawabnya masalah penelitian ini. Sumber data merupakan suatu informasi yang bersumber dari dokumen tertulis, benda-benda, kejadian atau peristiwa, atau bisa juga melalui wawancara dengan subyek yang diteliti[8].

Ada dua macam sumber data dalam penelitian ini yakni antara lain sebagai berikut :

a. Sumber data primer

Sumber data primer merupakan data yang diperoleh langsung dari obyek yang diteliti atau data yang diperoleh langsung pada waktu mengadakan penelitian yaitu dilapangan yang informasinya berasal dari informan.Sumber data yang utama yang akan peneliti mintai informasi tentang data-data yang mendukung penelitian ini adalah kepala sekolah, wakil kepala sekolah, guru PPKn, guru Agama, guru BP dan sebagian siswa.

b. Sumber data sekunder

Sumber data sekunder adalah sumber data pelengkap yang berfungsi untuk melengkapi datadata yang diperlukan oleh data primer sehingga diperoleh penelitian yang valid. Adapun sumber data sekunder yang diperlukan meliputi: hasil pengamatan (observasi) serta dokumen dokumen tentang SMP Negeri 10 Mataram sebagai penguat data primer.

Dalam penelitian ini peneliti menggunakan sumber data primer diperoleh melalui hasil wawancara sedangkan data sekunder diperoleh melalui dokumen-dokumen dan informasi lain yang terkait dengan penelitian.

5. Teknik Pengumpulan Data

a. Observasi

Observasi adalah dasar semua ilmu pengetahuan[9]. Pendapat lain menyatakan bahwa observasi adalah pengamatan dan pencatat secara sistematis dan terencana terhadap gejala-gejala fisik dan psikis objek yang diteliti untuk mendapatkan data tertentu[10]. Dengan demikian dapat dikatakan bahwa observasi adalah pengamatan atau penyelidikan yang digunakan dengan menggunakan alat indera, baik langsung maupun tidak langsung terhadap fakta-fakta atau gejalagejala yang akan diteliti. Teknik observasi digunakan untuk membuktikan kebenarannya data atau informasi yang diperoleh melalui wawancara.

Observasi adalah pengamatan secara langsung terhadap objek yang diteliti berupa hal-hal yang tampak dan melakukan pengamatan terhadap aktivitas-aktivitas yang sedang berlangsung terhadap sesuatu yang diteliti kemudian dideskripsikan dalam bentuk tulisan oleh peneliti. Sehingga peneliti sangat mudah untuk mengolah dan menganalisa data hasil observasi tersebut.

Adapun metode observasi yang digunakan peneliti adalah observasi tidak berstruktur dengan maksud untuk mengumpulkan data-data yang di perlukan agar 
peneliti memperoleh data yang valid dengan cara mendatangi langsung lokasi penelitian untuk melakukan pengamatan mengenai peran kepala sekolah sebagai supevisior dalam mengefektifkan proses pembelajaran PPKn Tahun Pelajaran 2017/2018 di SMP Negeri 10 Mataram.

\section{b. Wawancara}

Wawancara adalah pertemuan dua orang untuk bertukar informasi dan ide melalui tanya jawab, sehingga dapat dikonstruksikan makna dalam suatu topik tertentu[11]. Wawancara digunakan sebagai teknik pengumpulan data apabila peneliti ingin melakukan studi pendahuluan untuk menemukan permasalahan yang harus diteliti, tetapi juga apabila peneliti ingin megetahui hal-hal dari responden yang lebih mendalam.

Berdasarkan pengertian di atas dapat disimpulkan bahwa wawancara adalah hubungan antara dua orang yang saling berinteraksi dalam arti bertukar pikiran untuk memperoleh ide melalui proses tanya jawab.

Beberapa macam wawancara[11], antara lain:

1) Wawancara berstruktur (structured interview)

Wawancara berstruktur digunakan sebagai teknik pengumpulan data, bila peneliti atau pengumpul data telah mengetahui dengan pasti tentang informasi apa yang akan diperoleh. Dengan wawancara berstruktur ini setiap responden diberi diberi pertanyaan yang sama, dan pengumpul data mencatatnya.

2) Wawancara semiterstruktur (Semistrukture interview)

Jenis wawancara ini sudah termasuk dalam kategori in-dept interview, dimana dalam pelaksanaannya lebih bebas bila dibandingkan dengan wawancara terstruktur.

3) Wawancara tak berstruktur (unstructure interview)

Wawancara tak berstruktur adalah wawancara yang bebas dimana peneliti tidak menggunakan pedoman wawancara yang telah tersusun secara sistematis dan lengkap untuk pengumpulan datanya. Pedoman wawancara yang digunakan hanya berupa garis-garis besar permasalahan yang akan ditanyakan.

Dari apa yang sudah dijelaskan di atas maka peneliti menggunakan wawancara tak berstruktur dimana peneliti tidak menggunakan pedoman wawancara yang tersusun secara sistematis tetapi pedoman wawancara yang digunakan hanya berupa garis-garis besar permasalahan mengenai peran kepala sekolah sebagai supevisior dalam mengefektifkan proses pembelajaran PPKn Tahun Pelajaran 2017/2018 di SMP Negeri 10 Mataram.

\section{c. Dokumentasi}

Dokumentasi merupakan catatan peristiwa yang sudah ada[12]. Dokumen bisa berupa tulisan, gambar atau karya-karya monumental dari seseorang. Dokumen yang berbentuk tulisan misalnya catatan harian, sejarah kehidupan, cerita, biografi, peraturan, sedangkan dokumen yang berbentuk gambar misalnya foto, gambar hidup, sketsa dan lain-lain. Berdasarkan pendapat di atas dapat disimpulkan bahwa dalam teknik dokumentasi ini peneliti akan menggunakan, foto, hasil wawancara dengan subjek penelitian yang adadi SMP Negeri 10 Mataram .

\section{Teknik Analisis Data}

Analisis data adalah proses mencari dan menyusun secara sistematis data yang diperoleh dari hasil wawancara, catatan lapangan, dan dokumentasi, dengan cara menorganisasikan data ke dalam kategori, menjabarkan ke dalam unit-unit, melakukan sintesa, menyusun ke dalam pola, memilih mana yang penting dan yang akan dipelajari, dan membuat kesimpulan sehingga mudah difahami oleh diri sendiri maupun orang lain[4].

Analisis data dalam penelitian kualitatif dilakukan pada saat pengumpulan data berlangsung, dan setelah selesai pengumpulan data dalam periode tertentu. Pada saat wawancara, peneliti sudah melakukan analisis terhadap jawaban yang diwawancarai. Bila jawaban yang diwawancarai setelah dianalisis terasa belum memuaskan, maka peneliti akan melanjutkan pertanyaan lagi, sampai tahap tertentu, diperoleh data yang dianggap kredibel. Bahwa aktifitas dalam analisis data kualitatif dilakukan secara interaktif dan berlngsung secara terus-menerus sampai tuntas, sehingga datanya sudah jenuh. Aktifitas dalam analisis data reduction, data display dan conclusion drawing/verification[13];[4].

a. Reduksi Data (Data Reduction)

Digunakan untuk menarik kesimpulan dari beberapa data yang bersifat umum. Data-data yang bersifat khusus yang diperoleh dalam penelitian ini akan diolah supaya dalam penyajiannya akan menghasilkan generalisasi. Data yang diperoleh dari lapangan jumlahnya cukup banyak, untuk itu maka perlu dicatat secara teliti dan rinci. Seperti telah dikemukakan, semakin lama peneliti ke lapangan, maka jumlah data akan semakin banyak, kompleks dan rumit. Untuk itu perlu segera dilakukan analisis data melalui reduksi data. Mereduksi data berarti merangkum, memilih hal-hal yang pokok, memfokuskan pada hal-hal yang penting, dicari tema dan polanya. Dengan demikian data yang telah ada akan memberikan gambaran yang lebih jelas, dan mempermudah peneliti untuk melakukan pengumpulan data selanjutnya, dan mencarinya bila diperlukan[4].

Untuk mereduksi data peneliti membuat ringkasan,mengembangkan kategori dan membuat catatan yang bermaksud menajamkan, menggolongkan, mengarahkan yang tidak berlaku. Kemudian mengorganisasikan sedemikian rupa sehingga kesimpulan yang tepat, ini dilakukan terus- menerus selama penelitian berlangsung. Reduksi data di lakukan kepada informan peneliti (kepala sekolah SMP Negeri 10 Mataram dan Guru PPKn) kemudian memilih data-data yang paling penting dan yang menjadi fokus dalam 
penelitian kemudian mengelompokannya. Dengan demikian data yang direduksi dapat memberikan gambaran yang lebih jelas.

b. Penyajian Data (Data Display)

Digunakan untuk menarik kesimpulan dari beberapa data yang bersifat umum menjadi kesimpulan yang bersifat khusus. Data yang bersifat umum yang diperoleh dari informan akan diolah sesuai dengan spesifikasi yang terdapat dalam batasan masalah baik tempat, waktu, ataupun tema sehingga data-data tersebut sesuai dengan tujuan penelitian yang ingin dicapai oleh peneliti.

Berdasarkan uaraian diatas peneliti menggunakan penyajian data untuk mendapatkan hal-hal pokok yang diinformasikan dalam bentuk sederhana dan terpadu, sehingga dapat melihat apa yang sedang terjadi. Dalam penelitian ini data yang disajikan berupa hasil wawancara,observasi dan dokumentasi yakni menceritakan tentang peran kepala sebagai supervisor dalam mengefektikan proses pembelajaran PPKn di SMP Negeri 10 Mataram dan faktor pendukung serta penghambat dalam mengefektifkan proses pembelajaran PPKn di SMP Negeri 10 Mataram.Selanjutnya dirangkum dalam susunan yang lebih sistematis agar dapat diketahui tema dan polanya.Untuk memudahkan pola ini maka penelitian disajikan dalam bentuk matriks (kerangka/bagan) hasil penelitian.

\section{c. Verification/Conclucion Darwing}

Langkah ke tiga dalam penelitian kualitatif adalah penarikan kesimpulan dan verifikasi. Kesimpulan dalam penelitian kualitatif adalah temuan baru yang sebelumnya belum pernah ada. Temuan dapat berupa deskripsi atau gambaran suatu obyek yang sebelumnya masih remang-remang atau gelap sehingga setelah diteliti menjadi jelas, dapat berupa hubungan kausal atau interaktif, hipotesis atau teori.

Dari pola yang tampak dalam display data tersebut selanjutnya dapat ditarik suatu kesimpulan sehingga data yang dikumpulkan memiliki makna. Proses analisis dilakukan semenjak data awal dikumpulkan. Oleh karena itu kesimpulan yang ditarik pada awalnya bersifat sangat tentative atau masih kabur.Dengan demikian untuk menetapkan kesimpulan tersebut lebih berakar, maka verifikasi dilakukan dengan maksud untuk menjamin tingkat kepercayaan hasil penelitian sehingga prosesnya berlangsung sejalan dengan 'member check, triangulasi dan audit trail'.

\section{HASIL DAN PEMBAHASAN}

1. Peran kepala sekolah sebagai supervisor dalam mengefektifkan proses pembelajaran PPKn di SMP Negeri 10 Mataram

Kepala sekolah Di SMP Negeri 10 Mataram melaksanakan beberapa tahapan kegiatan supervisi yang dilakukannya guna membantu tercapainya tujuan yang ditetapkannya dalam bidang kepengawasan di sekolah. Sebelum kegiatan supervisi dilaksanakan, kepala sekolah melakukan kegiatan perencanaan yang berupa merumuskan program supervisi dengan melibatkan rapat kecil bersama beberapa guru senior dan wakil kepala sekolah. Langkah awal yang dilakukan adalah dengan membentuk Tim Pembantu Supervisor yang dibentuk oleh Kepala Sekolah. Tim Pembantu supervisor yang telah terbentuk direncanakan dapat membantu kepala sekolah dalam melaksanakan tugas supervisor yang diembannya dengan maksud mengefektifkan kegiatan supervisi di sekolah.

Para anggota dari Tim Pembantu Supervisor adalah guru-guru senior dengan kepangkatan yang berada di atas guru-guru yang disupervisor dan dianggap cakap atau mampu oleh kepala sekolah melaksanakan tugas supervisor secara baik dan tidak memihak, artinya mampu menilai apa yang sebenarnya terjadi. Tim Pembantu Supervisor yang selanjutnya disebut sebagai Tim Pembantu Supervisor Kepala Sekolah merumuskan jadwal kunjungan kelas dengan memantau jadwal jam mengajar para guru di Di SMP Negeri 10 Mataram yang akan disupervisor dengan maksud agar supervisi yang dilakukan tidak mengganggu kegiatan proses pembelajaran di sekolah mengingat Tim Pembantu Supervisor kepala sekolah juga guru yang aktif mengajar.

Hasil wawancara dengan Kepala Sekolah menyatakan bahwa,

"dalam 1 tahun saya sebagai kepala sekolah wajib menjalankan kegiatan supervisor terhadap para guru dalam 6 bulan sekali" (hasil wawancara tanggal o5 April 2018).

Kepala sekolah wajib melakukan supervisi kepada guru-guru SMPN 10 Mataram dalam setiap semester genap dan ganjil atau enam bulan sekali sesuai dengan jadwal yang ada.

Supervisi di laksanakan untuk semua guru, "supervisor yang saya lakukan untuk semua guru sesuai dengan jadwal yang sudah di buat oleh wakasek kurikulum tetapi, karena mengingat gurunya begitu banyak dan dismping itu juga ada beban kerja sebagai kepala sekolah maka saya hanya mensupervisor sebagaian guru saja dan sisanya dibantu oleh tim yang saya bentuk dimana guru-guru senior mensupervisor guruguru yunior. (Hasil wawancara tanggal o5 April 2018).

Supervisi harus sesuai dengan jadwal yang di buat oleh wakasek kurikulum dengan memperhatikan jadwal belajar dan kalender akademik pada awal semester. Di samping itu juga kepala sekolah harus mensupervisi semua guru untuk mengetahui kelemahan- kelemahan guru di kelas pada saat mengajar.

Wakasek sekolah, beliau menyatakan sebagai berikut: Guru yang perlu disupervisor yaitu guru yang mempunyai permasalahan dalam kelas seperti kurang tepat memilih metode mengajar, tidak sesuainya menggunakan sumber belajar, masalah dalam merencanakan dan 
melaksanakan. Jika dihadapakan pada guruguru yang demikian maka jelaslah mereka memerlukan bantuan supervisor (Hasil wawancara tanggal o5 April 2018)

Kepala sekolah secara langsung melakukan kegiatan supervisi kepada guru yang mempunyai permasalahan di kelas yang berkaitan dengan kurang tepat memilih metode mengajar, tidak sesuainya menggunakan sumber belajar, masalah dalam merencanakan dan melaksanakan, karena guru di tuntut untuk professional di dalam mengelola kelas.

Supervisi dilakukan di luar kelas, wakasek menyatakan bahwa:

Karena diluar kelas bersifat umum untuk semua guru maka saya melakukan supervisor admintarasi dengan cara membaca RPP yang dibuat guru setelah itu saya mengoreksinya kembali dengan menggunakan instrumen supervisor untuk menilai guru dalam pembuatan $R P P$ disamping itu juga saya melakukan secara spontan jika saya mendapat info bahwa akan dilakukan supervisor dari dinas pengawasan terhadap guru bersangkutan, hal ini dimksud agar guru tesebut sudah siap jika mendapat supervisor dari dinas pengawasan. (Hasil wawancara tanggal o5 April 2018)

Kepala sekolah terlebih dahulu memantau kinerja guru dengan cara memeriksa RPP, kesuaian materi dengan silabus serta media yang guru gunakan untuk mengajar, dengan cara atau tehnik yang tidak diketahui oleh guru sehingga hasil nya lebih nyata tanpa ada rekayasa.

Aspek supervisi kepada guru di dalam kelas Aspek yang disupervisor yaitu kelengkapan adminstrasi guru seperti RPP, daftar nilai, buku pegangan, bahan ajar, absen siswa dan yang lainya. Kempuan guru dalam mengelolah kelas penggunaan metode dan alat peraga. (Hasil wawancara tanggal o5 April 2018).

Dalam mengajar guru harus terlebih dahulu mempersiapkan segala perangkat pembelajaran seperti RPP, daftar nilai, buku pegangan, bahan ajar, absen siswa dan yang lainya.sehingga materi yang diajarkan terarah dan sesuai. Penggunaan media pembelajaran harus juga diperhatikan oleh guru, karena dengan menggunakan media pembelajaran akan memudahkan guru untuk menjelaskan materi yang diajarkan dan siswapun lebih mengerti dan paham terhadapt materi tersebut.

Apabila guru dalam mengajarnya ternyata masih banyak kekurangannya pada PBM, wakasek menyatakan bahwa:

Jika ada guru yang memiliki kekurang dalam Proses belajar mengajar maka tindak lanjut yang saya lakukan yaitu memanggil guru yang bersangkutan untuk memberikan pembinaan, arahan serta mencari solusinya untuk perbaikan selanjutnya (Hasil wawancara tanggal o5 April 2018).

Kepala sekolah akan memanggil guru yang bersangkutan untuk memberikan pembinaan dan memberikan solusi pemecahan masalah pengunaan media pembelajaran dan solusi yang diberikan bersifat positif yang tidak menjatuhkan guru serta tidak mempermalukan guru di depan umum.

Penilaian terhadap supervisor dilakukan untuk:

Hasil dari supervisor guru PPKn ini di jadikan bahan dasar untuk pembuatan penilaian kinerja guru (PKG) setiap setahun. Berdasarkan hasil penilaian pada guru PPkn Masih adanya kekurangan yang perlu di benahi baik dalam perencanaan administrasi pembelajaran, penggunaan metode, pengelolaan kelas dan penggunaan gaya bahasa. (Hasil wawancara tanggal o5 April 2018)

Hasil PKG Guru PPKn masih kurang dari standar, maka perlu dibenahi baik dalam perencanaan administrasi pembelajaran, penggunaan metode, pengelolaan kelas dan penggunaan gaya bahasa karena guru tersebut harus berusaha lebih keras lagi untuk memperbaiki kinerja mengajarnya di kelas karena berkaitan dengan profesionalitas guru.

Wakasek kurikulum dalam supervisi guru memiliki peran yakni:

Wakasek Kurikulum sangat berpengaruh terhadap jalannya kegiatan supervisi dan perannya di sini sangat membantu misalnya dalam membuat jadwal supervisi kelas.Sebelum saya melakukan supervisi kepada guru yang bersangkutan.(Hasil wawancara tanggal o5 April 2018)

Selain sebagai wakasek kurikulum bisa juga sebagai tim supervisi yang membantu kepala sekolah dengan mengatur jadwal supervisi sebelum melakukan sepervisi.

Bentuk supervisi pengawasan pendidikan kepada gurukepala sekolah menyatakan bahwa:

Bentuk supervisi yang dilakukan pengawas yaitu supervisi yang memberikan pelayanan terhadap guru yang mengalami kesulitan masalah dalam pembelajaran oleh karena itu supervise yang dilakukan pengawas ini juga memberikan dampak positif pada peningkatan kemampuan profesional guru.(Hasil wawancara tanggal 05 April 2018)

Supervisi yang dilakukan oleh pengawas yaitu supervisi Klinis yang memberikan pengarahan terhadap guru yang mengalami kesulitan dalam proses belajar mengajar agar dapat meningkatkan kemampuan guru tersebut.

Bentuk pengawasan dalam kegiatan supervisi, kepala sekolah menyatakan:

Pengawas pendidikan pernah melakukan supervisi berupa kunjungan kelas pada saat guru mengajar.Namun ada juga yang datang sekedar 
mengecek keadaan dan fasilitas sekolah.Selain itu pengawas juga datang secara tiba-tiba hal ini di lakukan karena ingin melihat dan memantau secara Rill bagaimana suasana pada saat PBM berlangsung.(Hasil wawancara tanggal o5 April 2018)

Pengawas dari dinas pendidikan melakukan kegiatan kunjungan kelas secara rutin akan tetapi yang di kunjunngi atau yang di pantau adalah guru yang berbeda-beda, pengawas juga melakukan kunjungan kelas secara dadakan, hal ini pengawas lakukan apabila mendapat laporan dari kepala sekolah mengenai kinerja guru yang kurang baik. Hal ini merupakan suatu kegitan supervisi untuk membinaan kinerja guru secara tidak langsung dan tidak disadari oleh kepala sekolah.

Sementara hasil wawancara dengan guru PPKn, menyatakan bahwa:

Pernah, 2 kali dalam 1 semester dan tahun kemarin saya di supervisi pada awal tahun pelajaran baru yaitu bulan Agustus.(Hasil wawancara tanggal 12 April 2018)

Supervisi yang dilakukan oleh kepala sekolah dalam setiap awal semester dan setelah mid semester pada semua guru termaksud guru PPKn agar dapat memperbaiki kelemahan-kelemahan pada saat proses belajar mengajar.

Sekolah mempunyai jadawal setiap semester untuk supervisi guru, hasil wawancara dengan guru PPKn, beliau menyatakan sebagai berikut:

Pastinya ada. Kepala sekolah tentu mempunyai jadwal supervisi, dan menyangkut pelaksanaanya ada guru yang sudah di supervisi dan ada yang belum karena ada kendala yang dialami oleh beliau.(Hasil wawancaratanggal 12 April 2018)

Pelaksanaan supervisi akademik oleh kepala sekolah terkadang tidak selalu tepat waktu, karena adanya beberapa pekerjaan yang harus dilaksanakan oleh kepala sekolah, maka dari itu pelaksanaan supervisor harus dilakukan bertahap dalam waktu enam bulan sekali.

Bentuk supervisi kepala sekolah di luar kelas bersifat umum, hasil wawancara dengan guru PPKn, beliau menyatakan sebagai berikut:

Diluar kelas beliau memberikan pengarahan atau pembinaan terhadap semua guru. Jika didapatkan ada beberapa guru yang mempunyai permasalahan yang sama maka beliau menggunakan pendekatan terhadap beberapa guru tersebut dengan diskusi kelompok.(Hasil wawancara tanggal 12 April 2018)

Kepala sekolah menggunakan pendekatan terhadap beberapa guru yang mempunyaipermasalahan yaitu mendengarkan permasalahan guru dengan mengadakan kegiatan rapat antar supervisor dengan para guru yang di supervisi, biasanya untuk membicarakan masalahmasalah umum yang menyangkut perbaikan atau peningkatan mutu pendidikan.
Supervisi dalam kelas pada hakekatnya adalah observasi di kelas dengan tujuan untuk menemukan kelemahan dan kelebihan guru mengajar sehingga dapat ditemukan permasalahan-permasalahan yang dijumpai guru untuk selanjutnya dibantu pemecahannya oleh supervisor secara demokratis.

Komponen nilai oleh kepala sekolah dalam supervisor guru, hasil wawancara dengan guru PPKn, beliau menyatakan sebagai berikut:

Yang dinilai oleh kepala sekolah yaitu Keserasian antara perangkat dengan proses pembelajaran melengkapi serta memperbaiki kekurangan dalam pembelajaran. (Hasil wawancara tanggal 12 April 2018)

Komponen-komponen yang dinilai kepala sekolah dalam administrasi pembelajaran adalah: program tahunan, program semester, silabus, Rencana Pelaksanaan Pembelajaran atau RPP, kalender pendidikan, jadwal tatap muka, agenda harian, daftar nilai, Kriteria Ketuntasan Minimal atau KKM dan absensi siswa.

Kalau sudah di supervisi dalam kelas apa tindak lanjut yang di lakukan oleh kepala sekolah kepada guru? Berdasarkan hasil wawancara dengan guru PPKn, beliau menyatakan sebagai berikut:

Tindak lanjutnya memberikan arahan kepada guru untuk melengkapi atau memperbaiki kekurangan dalam pembelajaran khususnya saya sendiri sebagai guru PPkn yang sudah pernah di supervisi.(hasil wawancara tanggal 12 April 2018).

Salah satu bentuk yang di lakukan oleh kepala sekolah yaitu berupa sharing kemudian mendengarkan penjelasan guru yang bersangkutan. Kegiatan ini dimaksudkan untuk mengetahui dan mengidentifikasi berbagai kesulitan dan kelemahan atau kekuatan guru selama proses pembelajaran.

Bentuk pembinaan yang di lakukan oleh pengawasan pendidikan, hasil wawancara dengan guru PPKn, beliau menyatakan sebagai berikut:

Saya sudah mendapatkan pembinaan dari pengawas dan selama 4 tahun mengajar disini saya di berikan pelatihan penyusunan perangkat K-13 pada kelas VIII dan kelas IX (Hasil wawancara tanggal 12 April 2018)

Pengawas sekolah memberikan kesempatan kepada guru-guru mengikuti berbagai pendidikan dan pelatihan di tingkat gugus atau kecamatan secara teratur, musyawarah guru mata pelajaran (MGMP), serta diskusi seminar lokakarya, dan penyediaan sumber belajar untuk dapat meningkatkan professional guru.

bentuk pembinaan yang di lakukan oleh pengawasan pendidikan, hasil wawancara dengan guru PPKn, beliau menyatakan sebagai berikut:

Saya sebagai guru PPKn pernah mendapatkan pembinaan dari pengawas dan bukan saya saja tetapi sebagian besar guru di sini mendapatkan 
pembinaan menyusun perangkat $K-13$. Di samping itu juga pengawas melakukan pengamatan yang intensif terhadap proses pembelajaran serta menindak lanjuti dengan pemberian feedback kepada guru-guru.(hasil wawancara tanggal 12 April 2018).

upaya-upaya yang dilakukan pengawas dalam memeperluas pengetahuan kompetensi guru, mereka melakukannya pelatihan-pelatihan, worksop dan mengikutsertakan MGMP baik kota maupun sekolah untuk kenaikan pangkat dan jabatan. Sedakangkan pengawas melakukan pengamatan yang intensif dengan memeriksa berkas administrasi guru yaitu: 1) kalender akademik, 2) program tahunan, 3) program semester, 4) analisis SK ( KD, 5) RPP, 6) buku absen, 7) buku nilai, 8) agenda pembelajaran, 9) buku supervisi, 10) kriteriaketuntasan minimal (KKM).

Pengawas pendidikan melaksanakan supervisi langsung ke kelas pada saat mengajar, berdasarkan hasil wawancara dengan guru PPKn, beliau menyatakan sebagai berikut:

Iya, tutor langsung melakukan in on (secara langsung dan tidak langsung) pada saat pelatihan tersebut guna di jadikan bahan penilaian terhadap kinerja guru. (hasil wawancara tanggal 12 April 2018).

Pengawas pendidikan melakukan observasi kelas secara langsung pada saat pelatihan untuk dapat memperoleh gambaran tentang kegiatan belajar mengajar di kelas guna di jadikan bahan penilaian terhadap kinerja guru.

Sebelum kegiatan supervisor akademik dilaksanakan, seperti pada keterangan di atas bahwa kepala sekolah melakukan kegiatan dalam bidang perencanaan yang berupa merumuskan program supervisi akademik dengan melibatkan rapat kecil bersama beberapa guru senior dan wakil kepala sekolah.Langkah awal yang dilakukan adalah dengan membentuk Tim Pembantu Supervisor yang dibentuk oleh Kepala Sekolah dan wakil. Para anggota dari Tim Pembantu Supervisor adalah guru-guru senior dengan kepangkatan yang berada di atas guru-guru yang disupervisor dan dianggap cakap atau mampu oleh kepala sekolah melaksanakan tugas supervisor akademik secara baik dan tidak memihak, artinya mampu menilai apa yang sebenarnya terjadi.

Hal ini juga sesuai dengan hasil penelitian[14] terdapat lima langkah utama dalam melakukan pengawasan atau supervisor, yaitu: (1) Menetapkan tolok ukur, yaitu menentukan pedoman yang digunakan; (2) Mengadakan penilaian, yaitu dengan cara memeriksa hasil pekerjaan yang nyata telah dicapai; (3) Membandingkan antara hasil penilaian pekerjaan dengan yang seharusnya dicapai sesuai dengan tolok ukur yang teah ditetapkan; (4) Menginventarisasi penyimpangan dan atau pemborosan yang terjadi (apabila ada); dan (5) Melakukan tindakan korektif, yaitu mengusahakan agar yang direncanakan dapat menjadi kenyataan.

Pada setiap akhir kegiatan supervisi akademik yang dilakukan, kepala sekolah melakukan tindak lanjut dengan mengadakan kegiatan pasca supervisor untuk merefleksi hasil supervisi yang telah dilakukan.Bentuk tindak lanjut yang dilakukan berupa sharing kemudian mendengarkan penjelasan guru yang bersangkutan. Kegiatan ini dimaksudkan untuk mengetahui dan mengidentifikasi berbagai kesulitan dan kebaikan atau kekuatan guru selama proses pembelajaran.

\section{Faktor pendukung dan faktor penghambat supervisor dalam mengefektifkan proses pembelajaran PPKn di SMP Negeri 10 Mataram}

Implementasi supervisor akademik kepala sekolah di SMP Negeri 10 Mataram dilaksanakan sesuai dengan program perencanaan supervisor akademik yang telah disusun oleh Kepala Sekolah bersama Tim Pembantu Supervisor Akademik Kepala Sekolah.Namun dalam pelaksanaannya dilapangan menemui berbagai bentuk kesulitan yang menjadi faktor penghambat kegiatan supervisor akademik kepala sekolah berdasarkan hasil monitoring dan evaluasi yang telah dilaksanakan.Walaupun juga ditemui berbagai faktor pendukung yang menjadi kekuatan dalam pelaksanaan supervisor akdemik yang telah dilakukan.

Secara nyata hampir setiap kegiatan selalu ada faktorfaktor yang mempengaruhi, begitu juga untuk kegiatan supervisor ini.Adapun faktor yang mempengaruhi pelaksanaan supervisor ini dibedakan menjadi dua yaitu faktor yang menghambat dan faktor yang mendukung.

a. Faktor-Faktor Penghambat

Ada berbagai faktor yang membuat pelaksanaan supervisor tergeser dan bahkan tidak dapat berjalan sebagaimana yang diharapkan.

1) Kesiapan diri guru

Kesiapan dari guru yang mau di supervisi, berdasarkan hasil wawancara menyatakan:

"Ya tentunya faktor kesiapan dari guru yang mau disupervisi (kesiapan administrasinya) dan supervisornya itu sendiri. Hal ini dapat juga mengakibatkan pelaksanaannya mundur. Tetapi yang jelas pelaksanaan supervisor ini bisa fleksibel. Seharusnya memang sesuai jadwal, tetapi kalau memang belum siap lantas dipaksakan ya nanti jadinya kita kurang harmonis dalam bekerja dengan sesama teman". (Hasil Wawancara tanggal 14 April 2018)

Jadi dalam hal ini kepala sekolah memberikan kebebasan kepada guru-guru untuk berkreasi. Dalam pelaksanaan supervisipun beliau tidak terkesan memaksa kepada bawahan harus seperti ini, tetapi pendekatan beliau lebih seperti teman dan 
santai, sehingga yang di supervisi merasa leluasa untuk menceritakanapasajakendalakendalayangdihadapi selamapembelajaran. Yang terpenting menurut kepala sekolah adalah bagaimana agar para dewan guru dan seluruh stafnya menjalankan seluruh kebijakan dengan tidak terbebani.

2) Jadwal supervisi

Kendala atau faktor yang menghambat dalam pelakasaan jadwal kegiatan supervisi, cukup bervariasi beliau menyatakan sebagai berikut:

Yang menjadi kendala dalam pelaksanaan supervisor ini yang pertama adalah kalender pendidikan kita terlambat datang. Ini membuat kita ragu dalam membuat program-program sekolah termasuk program supervisor. Kedua, guru kelihatannya kurang siap walaupun sebetulnya pemberitahuan pelaksanaan supervisi ini telah disampaikan pada saat rapat awal tahun ajaran baru. Hal ini dikarenakan memang kurikulum kita yang baru ini, jadi guru agak kurang memahami sehingga mereka kurang siap. (Hasil Wawancara tanggal o5 April 2018)

Faktor yang bisa menghambat pelaksanaan supervisor antara lain adalah: (a) kalender pendidikan, (b) kesiapan guru dan supervisor itu sendiri, (c) supervisor yang kurang profesional sehingga guru meragukan kemampuannya. Sementara itu berkaitan dengan faktor penghambat pelaksanaan supervisor, kepala sekolah sendiri belum bisa menyatakannya secara pasti apa kendalanya, seperti yang dikatakannya sebagai berikut:

Kendala lain dalam pelaksanaan supervisi terhadap guru, hasil wawancara menyatakan:

Kendala secara persisnya ya belum jelas.

Tapi tanggapan guru terhadap pendelegasian supervisor masih disikapi beragam, mungkin perlu penjelasan kembali tentang supervisor ini ke guru-guru. Dari sisi jadwal mungkin juga ada. Nantilah kalau sudah ada evaluasi lengkap supervisor di akhir tahun, baru jelas mana kelebihan dan kekurangan pelaksanaan supervisor sekarang ini. (Hasil Wawancara tanggal 05April 2018)

Menghambat pelaksanaan supervisor ini yaitu tentang kondisi guru yang kurang memahami arti penting dari pelaksanaan supervisor, sehingga kepala sekolah perlu memberikan penjelasan kembali tentang supervisor.Sementara guru-guru juga telah memberikan tanggapannya berkaitan dengan faktor penghambat pelaksanaan supervisor tersebut. b. Faktor-Faktor Pendorong

Faktor pendorong yang dimaksud merupakan faktor yang dapat memberikan motivasi dalam pelaksanaan supervisor kepala sekolah. Faktor pendorong ini tentu diawali dari keinginankeinginan guru selaku orang yang disupervisor.Karena dalam supervisor kelas guru merupakan obyek utama dalam observasi. Oleh karena itu berdasarkan hasil wawancara dengan beberapa guru dan staf diperoleh gambaran faktorfaktor pendorong dalam pelaksanaan supervisor.

Hasil wawancara dengan Kepala sekolah, menyatakan bahwa:

Ya tentunya perencanaan harus matang (jadwal dll). Pelaksanaan harus tepat, informasi jelas, diingatkan dan disosialisasikan terlebih dahulu. Ini tentunya kewajiban PKS dan Kurikulum. (Hasil Wawancara tanggal o5 April 2018)

Faktor yang mendukung supervisi individual adalah adanya kesiapan guru yang matang dalam mengajar utamanya administrasi pembelajaran. Para guru selalu siap untuk disupervisor oleh kepala sekolah karena menyadari bahwa kegiatan supervisor akademik yang dilakukan kepala sekolah adalah untuk memberikan masukkan yang berharga bagi kebaikan proses dan hasil pembelajaran yang dilakukan guru di sekolah. Selain itu kegiatan supervisor akademik menurut guru melalui hasil penelitian merupakan kegiatan yang dapat memotivasi para guru untuk melaksanakan tugas mengajar dengan penuh tanggung jawab dan profesional.

Faktor pendorong seorang supervisior sebagai pemimpin dalam pelaksanaan supervisi? Berdasarkan hasil wawancara dengan Kepala sekolah, beliau menyatakan sebagai berikut:

Yang pertama tentunya dari unsur pimpinan itu sendiri, pengkondisian supaya supervisor dapat berjalan dengan baik, kemudian para supervisor secara psikis juga diberikan arahan sehingga kita bisa berjalan kompak dan tidak masing-masing harus meraba-raba sendiri kerjanya, serta guru diberikan penjelasan secara umum tentang perlunya dilaksanakan supervisor dan kenapa kita yang ditugasi sebagai supervisor dan seterusnya supaya kita semua memahami secara murni dan jernih. (Hasil Wawancara tanggal o5 April 2018).

Sebagai pelaksana kegiatan belajar mengajar yang bertugas mengarahkan, meberikan informasi, membimbing serta merubah situasi kelas menjadi situasi yang sangat mneyenangkan sehingga tujuan belajar mengajar dapat tercapai dengan sempurna, serta guru diberikan penjelasan secara umum tentang perlunya dilaksanakan supervisor dan 
kenapa kita yang ditugasi sebagai supervisor dan seterusnya

Pendapat-pendapat tersebut dapat disimpulkan bahwa faktor-faktor yang dapat mendukung/memotivasi pelaksanaan supervisor dapat dikelompokkan menjadi 2 yaitu menurut guru dan para supervisor. Faktor pendorong menurut guru adalah: (1) perencanaan harus matang, (2) pelaksanaan harus tepat, (3) informasi kepada guru sebagai subyek yang diobservasi harus jelas, dan (4) sebelum pelaksanaan harus disosialisasikan lebih dulu.

Adapun faktor pendorong menurut tim supervisor adalah: (1) Secara psikis supervisor diberikan arahan oleh kepala sekolah supaya kerja tim dapat kompak dan tidak ada interpretasi masing-masing yang sifatnya subyektif, (2) guru juga diberikan penjelasan dan arahan arti pentingnya pelaksanaan supervisor, dan (3) agar dijelaskan alasan pendelegasian ini sehingga guru dapat menerima dengan baik kehadiran tim supervisor.

Pelaksanaan supervisor akademik dilapangan menemui berbagai bentuk kesulitan yang diidentifikasi menjadi beberapa faktor penghambat kegiatan supervisor akademik kepala sekolah berdasarkan hasil monitoring dan evaluasi yang telah dilaksanakan dan ditemui berbagai faktor pendukung yang menjadi kekuatan dalam pelaksanaan supervisor akdemik yang telah dilakukan.

Faktor pendukung implementasi supervisor akademik adalah kepala sekolah memberikan kebebasan kepadaguru-guruuntukberkreasi.Dalam

pelaksanaansupervisipunbeliau

tidakterkesanmemaksakepadabawahanharussepertiini, tetapipendekatan beliau lebih seperti teman dan santai, sehingga yang di supervisi merasa leluasa untuk menceritakan apa saja kendala-kendala yang dihadapi selama pembelajaran. Yang terpenting menurut kepala sekolah adalah bagaimanaagar para dewan guru dan seluruh stafnya menjalankan seluruh kebijakan dengan tidak terbebani, karena nantinya yang menjalankan adalah mereka sendiri, kepala sekolah hanyalah pengambil kebijakan.

Hal ini juga sesuai dengan pendapat Nawawi Setiap guru harus memahami fungsinya karena sangat besar pengaruhnya terhadap cara bertindak dan berbuat dalam menunaikan pekerjaan sehari-hari di kelas dan di masyarakat. Guru yang memahami kedudukan dan fungsinya sebagai pendidik profesional, selalu terdorong untuk tumbuh dan berkembang sebagai perwujudan perasaan dan sikap tidak puas terhadap pendidikan.Persiapan yang harus diikuti, sejalan dengan ilmu pengetahuan dan teknologi[15].

Faktor penghambat dalam supervisi oleh kepala sekolah adalah kesibukan pekerjaan karena terkadang ada beberapa pekerjaan yang sifatnya mendadak harus dikerjakan sehingga kegiatan supervisi akademik yang dilakukan tidak sesuai dengan program yang telah disusun sebelumnya. Kendala lain yang dihadapi oleh kepala sekolah dalam melakukan peningkatan kinerja guru di sekolah adalah kurangnya sarana dan prasarana peningkatan kinerja guru. Selama ini kegiatan peningkatan yang dilakukan kepala sekolah adalah melalui prosedur yang sederhana dan sarana maupun prasarana yang terbatas.Peningkatan ini memerlukan sarana dan prasarana yang memadai, sehingga dalam pelaksanaannya mampu diwujudkan sesuai dengan tujuan yang diharapkan. Sarana dan prasarana tersebut akan mempengaruhi hasil peningkatan, dikarenakan kepala sekolah merasa kesulitan untuk melakukan peningkatan.

Sarana pendidikan adalah peralatan dan perlengkapan yang secara langsung digunakan dan menunjang proses pendidikan, khususnya proses belajar mengajar, adapun yang disebut prasarana adalah fasilitas yang secara tidak langsung menunjang jalannya proses pendidikan atau pengajaran. Adanya sarana prasarana yang lengkap juga dapat meningkatkan Kwalitas guru. Guru akan lebih kreatif dalam menggunakan fasilitas yang ada, menggunakan sesuai dengan meteri yang diajarkan[16].

\section{SIMPULAN DAN SARAN}

Hasil penelitian menunjukkan bahwa kepala sekolah melakukan supervisi observasi kelas untuk mengamati secara langsung terhadap guru yang melaksanakan proses belajar mengajar yaitu melihat kemampuan guru dalam penguasaan materi pelajaran, kemampuan menggunakan metode pembelajaran, kemampuan mengelola kelas dalam interaksi belajar mengajar serta kemampuan dalam melakukan evaluasi hasil belajar. Hasil dari pengamatan tersebut sebagai bahan kepala sekolah dalam membina guru terhadap hal-hal yang dianggap masih kurang dikuasai oleh guru.

Kepala sekolah melakukan pembinaan melalui rapat guru setiap awal semester untuk memberikan motivasi kepada guru agar dalam melaksanakan tugasnya secara profesional yaitu terutama dibidang pedagogik dan profesional. Faktor pendukung dan faktor penghambat supervisor akademik.

Faktor pendukung supervisor akademik adalah para guru selalu siap untuk di supervisi oleh kapala sekolah karena menyadari bahwa kegiatan supervisi akademik yang di lakukan kepala sekolah adalah untuk memberikan masukan yang berharga bagi kebaikan proses dan hasil pembelajaran yang dilakukan guru di sekolah. Sedangkan faktor penghambat supervisor akademik ini adalah kesibukan pekerjaan yang sifatnya mendadak yang harus di kerjakan oleh kepala sekolah sehingga kegiatan supervisi yang di lakukan tidak sesuai dengan program yang telah disusun sebelumnya. Di sampng itu adanya beberapa kesulitan yang dialami oleh kepala sekolah yang berupa jika kepala sekolah mensupervisi guru yang bukan bidang studi yang menjadi background pendidikan kepala sekolah.

\section{UCAPAN TERIMA KASIH}

Penulis mengucapkan terima kasih kepada editor yang senantiasa memberikan saran dan masukan kepada penulis sehingga artikel ilimiah ini selesai dengan baik. 


\section{DAFTAR RUJUKAN}

[1] Wahjosumidjo, Kepemimpinan kepala sekolah: tinjauan teoritik dan permasalahannya. Rajagrafindo Persada (Rajawali Pers), 1999.

[2] E. Mulyasa, "Menjadi guru profesional," Bandung: Remaja Rosdakarya, 2005.

[3] L. J. Moleong, Metodologi penelitian. 1999.

[4] P. Sugiyono, Metode Penelitian Kuantitatif, Kualitatif, dan $R \& D .2013$.

[5] A. Suharsimi, "Prosedur penelitian suatu pendekatan praktik," Jakarta: Rineka Cipta, 2006.

[6] A. Sugiyono, "Pengantar Statistik Pendidikan," Jakarta Graf. Persada, 2004.

[7] S. Djam'an, "Profesi Keguruan," Jakarta Univ. Terbuka, 2007.

[8] N. Sudjana, Belajar dan Faktor-faktor yang Mempengaruhinya. 2010.

[9] S. Nasution, Berbagai pendekatan dalam proses belajar dan mengajar. PT. Bina Aksara, 2000.

[10] K. Kartono, "Metode Penelitian Bidang Sosial." Jakarta: Grafindo Perkasa, 2005.

[11] K. G. Esterberg, "Qualitative methods in social research," 2002.

[12] P. Sugiyono, "Dr. 2010," Metod. Penelit. Kuantitatif, Kualitatif, dan R\&D. Bandung CV Alf.

[13] M. B. Milles, "Huberman. 1984. Qualitative Data Analysis." London: Sage Publication.

[14] M. Asrori, "Psikologi pembelajaran," Bandung: Wacana Prima, 2007.

[15] H. Nawawi, Administrasi pendidikan. PT Toko Gunung Agung, 1995.

[16] S. Sulistyorini, "Model pembelajaran IPA sekolah dasar dan penerapannya dalam KTSP," Yogyakarta: Tiara Wacana, 2007. 